\title{
A evolução da carreira
}

\section{NO VELHO MUNDO ARISTOCRÁTICO, NÃO FAZIA SENTIDO FALAR EM CARREIRA. A NOÇÃO DO MÉRITO INDIVIDUAL NÃO ESTAVA PRESENTE NAQUELAS SOCIEDADES, ORGANIZADAS EM TORNO DAS HIERARQUIAS DAS LINHAGENS NOBRES. SER OU NÃO DA NOBREZA NÃO DEPENDIA DO ESFORÇO DE CADA UM, NASCIA-SE NOBRE E DE SANGUE AZUL}

A vida de Mozart, analisada por Norbert Elias, mostra que, apesar das competências do artista, ele sempre foi considerado um "criado superior", que animava as festas e a convivência no castelo, jamais nobre! A distinção entre nobreza e camponeses era marcada por uma desigualdade intransponível.

A noção de carreira aparece no século XIX, quando da organização da sociedade industrial. Nessa transição para o mundo do capital, representada em filmes, como O leopardo, de Visconti, a convivência entre uma nobreza arruinada e uma burguesia enriquecida provocava conflitos.

A ideia de que uma pessoa possa ter méritos e que estes possam the dar algum lugar numa organização social só foi possível associada ao mundo do capitalismo industrial, organizado em torno do trabalho. Em outras palavras, a noção de carreira é muito recente na história da humanidade, assim como a noção de orientação vocacional.

Segundo Chanlat, a sociedade industrial nasce de idéias de igualdade, liberdade e de êxito individual, especialmente nos EUA, o lugar por excelência do self made man. Apesar das muitas contradições que permearam o desenvolvimento desse país, como questões raciais e de gênero, foi lá que muitos empreendedores começaram e desenvolveram seus negócios e o protótipo do modelo moderno de carreira.

Chanlat mostra ainda que as condições de carreira precisam ser entendidas dentro das especificidades da cultura de cada país, mas, de modo geral, as sociedades capitalistas permitiram o desenvolvimento de classes médias e de certa mobilidade social que garantiu a afirmação dos direitos individuais.

O clássico trabalho de Bresser-Pereira "The rise of middle class and middle management in Brazil" mostra como esse processo ocorreu em nosso país, que deixa de ser essencialmente agrícola e começa a ter um modelo de industrialização que inclui o desenvolvimento de gestores, o crescimento das camadas médias nas cidades e, evidentemente, todas as mudanças sociais que dele decorreram. A criação da FGV-EAESP está inserida nesse processo que levou à necessidade de profissionais qualificados para o desenvolvimento industrial de São Paulo.

Com o desenvolvimento do capitalismo industrial no início do século XX e logo após a 2a Guerra Mundial, a carreira era para os homens, com a perspectiva de uma progressão linear sempre ascendente.

Esse modelo continuou até os anos 1980, quando crises econômicas e a reorganização da produção levaram a mudanças nessa concepção. Além disso, a partir dos anos 1970, observa-se o questionamento da condição feminina no mercado de trabalho.

O modelo contemporâneo de carreira não garante mais a estabilidade e a ascensão linear vertical do início. Homens e mulheres estão presentes no mercado de trabalho, e uma distinção passou a ser feita entre "emprego" e "trabalho". O cenário atual permite alguma flexibilidade, exige cada vez mais competências acadêmicas, linguísticas, mas também desenvolvimento emocional para lidar com a complexidade crescente das grandes organizações; ao mesmo tempo que se incentiva a veia empreendedora e a criatividade para a proposição de soluções inovadoras e a sustentabilidade do planeta. $\boldsymbol{x}$
Maria José Tonelli FGV-EAESP maria.jose.tonelli@fgv.br 